\title{
THE MASTERS DEGREE IN DEPARTMENTS OF NURSING SCIENCE AT SOUTH AFRICAN UNIVERSITIES: TYPES, GROWTH AND POLICY DIFFERENCES AND SIMILARITIES
}

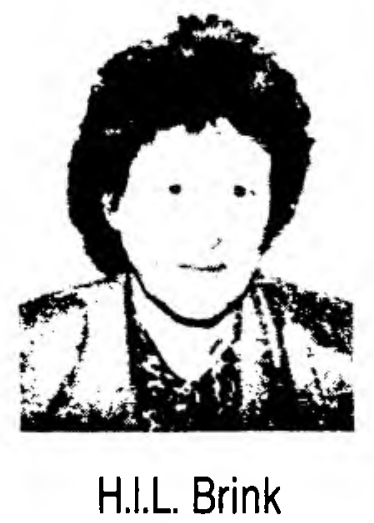

\section{Abstract}

In this exploratory study nine masters programmes in nursing were surveyed to establish the types of programmes available, the growth of masters students over the years and the policies governing each programme. Data were collected by means of a questionnaire developed by the investigator. From the findings it could be established that considerable variation existed in the type of form of degree offered, that growth was steady but slow and that both similarities and differences existed in the policies of the departments. Several areas were identified for additional research.

\section{Opsomming}

In hierdie verkennende studie is 'n opname van nege Magister in Verpleegkunde programme gedoen met die doel om die volgende te bepaal: die tipe programme wat aangebied word, die groei van magister studente oor die jare en die onderliggende beleid van elke program met betrekking tot toelating, begeleiding en eksaminering van magister kandidate. Data is deur middel van ' $n$ vraelys wat deur die ondersoeker ontwikkel is versamel. Dit is gevind dat daar aansienlike verskille is met betrekking tot die tipe en aard van program wat aangebied word en dat groei bestendig maar stadig is. Verder is ooreenkomste sowel as verskille gevind tussen die beleid van die verskeie departemente.

\section{INTRODUCTION}

Masters programmes in nursing at South African Universities are of relatively recent origin. The first programme was

introduced by the University of Pretoria in 1967. Three specialty area options namely nursing education, nursing administration and clinical subjects were provided for in this first programme (Searle 1968:98). The masters programme in advanced nursing education was opened to graduate nurses who were already qualified tutors so as to enable them to specialise in advanced nursing education. To be admitted to the course candidates had to furnish proof of at least two years post-registration experience as a tutor. The masters programme in nursing administration had similar requirements applicable to nurse administrators. The masters programme in advanced clinical studies had a nursing education component built in, in addition to the normal requirements of a masters degree and was open to nurses who had obtained a bachelors degree in nursing.

For each speciality area both course work and a mini-dissertation on an approved subject in the field were required. With regard to the course work, the core content was taught in the nursing department. This amounted to approximately $60-70 \%$ of the total course. Of the remainder, part was taken in common with medical students and part in common with post-graduate social science, public administration or general education courses depending on the specialty area selected.

By 1970 a total of nine nurses had successfully completed the masters degree in nursing at the University of Pretoria. Of these two were in Nursing Administration, three in nursing education and four in clinical subjects (one in Advanced Midwifery and three in Intensive Nursing Care). A further nine were still busy with the course at this University while four nurses had registered for a masters degree in nursing, viz. three in Intensive Nursing Care and one in Midwifery and Gynaecological nursing at the University of the Orange Free State (Kotze 1970:124).

By 1987, twenty years after the University of Pretoria had taken the lead to initiate masters programmes in nursing, the number of Universities in the country offering such programmes had isen to 11 . At this time very little published material was available on the nature and form of the masters programme offered by the 11 different Departments of Nursing.

In view of the fact that the type of degree offered by University departments 
is normally dependent upon requirements set by the University and that criteria governing the admission and completion requirements are generally based on the policies of the institution concerned, it was surmised that the masters programmes in nursing would be characterised by considerable diversity in form, organisation and requirements for admission and completion. Given this background, it was considered timely to ascertain by means of a survey what types of masters programmes in nursing currently existed in this country and what procedures, practices and criteria governed the admission, training and examining of masters students in Departments of Nursing Science at South African Universities.

The major aim was to gain some insight into the wide range of alternative programmes available and the criteria used by colleagues in nursing departments on aspects pertaining to masters programmes and to share the latter with all colleagues offering masters programmes or intending to enrol for such programmes. A further aim was to compare the findings with findings of a similar study in another field. In this way it may be possible to detect inconsistencies in ones programmes and given attention to them.

\section{DESCRIPTION OF THE STUDY}

The survey approach was utilised to implement the exploratory design of the study. The population, which was comprised of 11 cases, consisted of the head or her deputy of each of the university departments of nursing science in the country, where masters programmes in nursing were being offered during 1987.

Data were collected through the use of a questionnaire which was mailed to the Heads of all the nursing departments comprising the population. The questionnaire, developed by the investigator was based on one which had been used in a survey of masters degrees in the Departments of English in South Africa (Pereira 84:29-31). It included 1) a face sheet which contained a request for questionnaire completion and 2) a fourpage answer sheet that included questions on selected aspects relating to the masters degree in nursing. Since the focus of concern of this study was to gain insight into the types and growth of masters programmes in nursing currently existing in this country and to ascertain the departmental policies governing the admission, training and examining of masters students in nursing, questions relating to curriculum content and design were not included.

The following aspects were covered

- year in which the programme was established

- number of candidates who have completed the programme

- number of candidates currently registered for the programme

- the title of the degree

- prerequirements and criteria for admission
- form of the masters degree

- nature of supervision, appointments and duties of supervisors

- formal requirements governing the dissertation

- examiners and examining.

Most of the questions were of the forced choice type and required only check marks as responses. Spaces were provided for any additional comments the respondents cared to make. The time required for answering the questionnaire was estimated to be approximately 5-10 minutes.

Reliability testing was not done. By September 1987 nine of the eleven questionnaires ( $82 \%$ ) had been returned. A message had been received from the Head of a tenth department that she was not willing to participate in the survey as her programmes were being revised

\section{RESULTS}

As no permission had been requested to use the names of the Universities concerned in connection with the findings only a general summary of responses from all nine participating respondents is presented.

Findings indicated that definite similarities but also considerable variations existed between the departments under study.

\section{DEVELOPMENT OF MASTERS PROGRAMMES IN NURSING}

Table 1 depicts in chronological order the years in which the masters programme in nursing was first established and first offered by each of the nine participating nursing departments. As indicated the process of development of masters programmes in nursing was steady but slow. Almost one-half of the programmes were initiated in the present decade. The majority of masters students following nursing programmes are enrolled parttime.

\begin{tabular}{|ccc|}
\hline \multicolumn{3}{|c|}{ TABLE 1 } \\
$\begin{array}{c}\text { Chronological Development of Masters } \\
\text { Programmes in Nursing at South African } \\
\text { Universities* }\end{array}$ \\
University & Year first offered & Year established \\
A & 1967 & 1967 \\
B & 1973 & 1970 \\
C & 1974 & 1972 \\
D & 1974 & 1971 \\
E & 1978 & 1975 \\
F & 1980 & 1978 \\
G & 1980 & - \\
H & 1987 & 1973 \\
I & 1987 & 1982
\end{tabular}

- Data are incomplete as two universities did not provide information.

NUMBER OF CANDIDATES WHO HAVE COMPLETED AND NUMBER WHO ARE CURRENTLY REGISTERED FOR THE MASTERS DEGREE IN NURSING

The number of candidates who have completed the masters in nursing programmes and the number who are currently registered at each of the nine universities surveyed are presented in Table 2. Even though the figures reflected are not a true reflection of the total number of masters prepared nurses in South Africa as the figures from two universities are missing, they nevertheless indicate the very slow growth of masters prepared candidates during the past two decades. Of a total of 69347 registered nurses (1988 SANC figures) not even $0,25 \%$ are prepared at masters level.

\begin{tabular}{|c|c|c|}
\hline \multicolumn{3}{|c|}{ TABLE 2} \\
\hline \multicolumn{3}{|c|}{$\begin{array}{c}\text { Number of Candidates who I/ Have Completed } \\
\text { and 2) Are Currently Registered for Masters } \\
\text { Programmes in Nursing at South African } \\
\text { Universities* }\end{array}$} \\
\hline University & Completions & Current registration \\
\hline A & 49 & 02 \\
\hline B & 08 & 21 \\
\hline C & 03 & 04 \\
\hline D & 07 & 13 \\
\hline $\mathrm{E}$ & 22 & 25 \\
\hline $\mathrm{F}$ & 37 & 45 \\
\hline G & 01 & 01 \\
\hline H & 00 & 08 \\
\hline I & 00 & 02 \\
\hline Total & 127 & 121 \\
\hline \multicolumn{3}{|c|}{$\begin{array}{l}\text { * Data are incomplete as two universities did not } \\
\text { provide information. }\end{array}$} \\
\hline
\end{tabular}

\section{TITLES OF MASTERS IN NURSING DEGREES}

Several different degrees are awarded on completion of the masters programme in nursing. At several universities the title of the degree appears to be related to the nature of the faculty in which the nursing department is located. Of the nine universities surveyed, three award an M.Cur degree, two an M.Sc. Nursing, while the remaining 5 award a M.A.Cur., a M.Soc.Sc., a M.Art. et Scient. and M. Verpl. respectively.

\section{PREREQUIREMENTS AND \\ CRITERIA FOR ADMISSION}

Prerequirements for admission to masters programmes in nursing vary according to the universities. Five universities will admit students who are in possession of a four year bachelors degree in nursing or equivalent directly into the Masters programme. One of these five universities will also admit registered diploma nurses who hold additional diplomas in Nursing Administration and Nursing Education, with the provision that the prospective candidate may be required at the discretion of the Head of the Department to present herself for an oral examination. Three universities require at least an Honours degree in Nursing or equivalent, while the ninth university required a post-basic nursing degree (e.g. B.A.Cur or B.Cur.I et A.) with a grade point average of at least $65 \%$ up to 1987 . These prerequirements were to be changed to an Honours degree from 1988 onwards.

A basic course in research methods and/or statistics is a further 
TABLE 3

Respondent's Rutings of Suggested Admission Criteria $(N=I 1)$

Admission criteria

Availability of a specialist superviso

Students record and examination performance to date

Choice of an acceptable topic

Outline of projected dissertation

Potential value of dissertation

Topic has bearing on major subject taken for bachelors degree

Topic has bearing on content area of Honours degree Other

$\begin{array}{cc} & \text { Rating } \\ \text { Important } & \text { Neutral } \\ 7 & 2 \\ 7 & \\ 5 & 2 \\ 5 & 2 \\ 5 & 2 \\ 5 & 2 \\ 5 & 2 \\ \end{array}$

Unimportant

2

2

2

2 prerequirement to masters programmes in nursing at six universities. At four of these universities such a course is offered at Honours level or in the 4 years basic nursing degree programmes - while the remaining two universities require their students to take a specially designed course in conjunction with Education students, before permitting them to proceed with their Masters dissertation. Three Universities do not lay down any prerequirements with regard to research methods and/or statistics.

Ratings by respondents to admission criteria which were suggested in the questionnaire are depicted in Table 3. As reflected, there is no consensus with regard to any single criterium. All criteria received support from the majority of respondents, however of the six criteria five were rated as unimportant by at least two respondents. Availability of a specialist supervisor can be singled out as the only admission criterium which counts heavily at each one of the universities. Only one respondent included an additional criterium, namely "the student is recognised as a leader in the profession", which she rated as fairly important.

\section{FORM OF THE MASTERS DEGREE}

The following forms of masters degrees

were taken into account:

dissertation only

dissertation plus one or more written

papers

dissertation or written papers

written papers and mini dissertation written papers only.

None of the nine nursing departments under study have made provision for the last two options listed above. At five universities, students can obtain their masters degree in nursing by means of a dissertation alone. At the other four universities students have alternative options depending on the nature of the specialty area selected, namely a dissertation alone or a mini dissertation and written examinations. The number of written papers required vary according to university, from two papers to at least three papers, 3 papers and an oral examination or 5-6 papers.

At three of the universities the nursing programmes are designed in such a way that on completion students are eligible to apply to the South African Nursing Council for registration of their additional clinical qualification, such as advanced midwifery, advanced psychiatric nursing or intensive care nursing. At one university provision is made in all masters programmes offered in the nursing department (viz clinical nursing, nursing education and nursing administration) for students to be eligible to register the relevant additional qualification with the South African Nursing Council. Five universities have not made such a provision.

All but two of the nursing departments under study offer a variety of specialty area options in their masters programmes. Students have a choice of specialising in nursing education, nursing administration or in one of several clinical specialty areas. At one university the clinical specialty area is limited to community health, while at another one the student has options for either community health or advanced psychiatric nursing but not for other clinical specialties. Two respondents indicated that they do not focus on clinical specialty areas, but provided no further information.

\section{ASPECTS RELATING TO SUPERVISORS AND NATURE OF SUPERVISION}

Criteria for appointment of supervisors

When appointing supervisors for students following the masters in nursing programmes, their expertise in the field in which the student wants to specialise counts most heavily in seven nursing departments.

In two departments the highest priority is placed on academic qualifications. A further criteria listed by two respondents is the person's special interest in the field. No other criteria were referred to by any of the respondents.

\section{Issuing of guidelines regarding the supervisors' responsibilities}

Guidelines which indicate the nature and scope of the supervisors responsibility vis a $v i s$ the masters candidate are issued by only four departments. Two of the respondents included a copy of such guidelines issued by their university which had been adapted for their department. One respondent did not reply to the question and four indicated they do not issue any guidelines regarding the supervisors' responsibilities.
Most important duties of the supervisor In response to an open question "What do you regard the most important duties of the supervisor", a variety of answers were received. These are presented in Table 4.

\begin{tabular}{|c|c|}
\hline \multicolumn{2}{|c|}{$\begin{array}{c}\text { TABLE } 4 \\
\text { Most Important Duties of Supervisors of Masters } \\
\text { Students as Stated by Respondents }\end{array}$} \\
\hline Duties of Supervisors & $\begin{array}{l}\text { Number of } \\
\text { respondents }\end{array}$ \\
\hline $\begin{array}{l}\text { Guide and encourage student } \\
\text { Set standard and ensure that } \\
\text { standard is met }\end{array}$ & 5 \\
\hline $\begin{array}{l}\text { Constructively criticise and give } \\
\text { feedback }\end{array}$ & 4 \\
\hline $\begin{array}{l}\text { Help student refine protocol and } \\
\text { develop a work plan }\end{array}$ & 2 \\
\hline $\begin{array}{l}\text { Advise on resources } \\
\text { Check submitability } \\
\text { Be available } \\
\text { Be a scientific role model }\end{array}$ & $\begin{array}{l}2 \\
1 \\
1 \\
1\end{array}$ \\
\hline
\end{tabular}

\section{FORMAL REQUIREMENTS} REGARDING THE DISSERTATION

Chapter by chapter submission of the dissertation was expected by all nine nursing departments under study. Differences of opinion were found with regard to the duties of the supervisor in respect of the final draft of the dissertation. One nursing department did not consider final vetting of the entire completed draft necessary.

One respondent expected the supervisor to carefully work through the document and make amendments and corrections where necessary. Another respondent stated that the final draft should be critically evaluated for correctness of research, use of language and technical skills. If consistencies or inaccuracies were found these should be brought to the attention of the candidate, who would have to correct them. Under no circumstances should the supervisor correct or amend a student's work. Three respondents stated that it was the duty of the supervisor to satisfy herself that the dissertation is ready to be submitted for examination. The latter respondents provided no further information. Three respondents refrained from answering this question.

All departments have basic guidelines governing the technical requirements of a dissertation. These are laid down in the university regulations relating to masters degree. Six departments have basic guidelines regarding the form of the dissertation, three regarding the scope and two regarding the length.

\section{EXAMINERS AND EXAMINING}

There does not appear to be a uniform policy with regard to the number of examiners appointed for examining the dissertation. Five universities appoint two examiners, three universities appoint three and one university four. At no university is there a wholly internal examining panel. Every university appoints at least one external examiner. The ratio of internal to 
external examiner varies from $1: 1$ to $1: 2$ to $2: 1$ to $2: 2$. One respondent indicated that the ratio was $1: 1$ but that this did not include the supervisor.

In two of the nursing departments students get told who their examiners are, while in 7 departments they do not.

At five of the universities students are informed of the mark obtained, and at all nine universities under study students are informed of reasons for non-acceptance of their dissertation should this occur.

There is general agreement on a division of marks into the categories of Fail. Pass (at least 50\%) and distinction (at least 75\%). There are however no other specific criteria indicating what to look for in differentiating between fail, pass and distinction.

\section{CRITERIA FOR DIFFERENTIATING BETWEEN A DOCTORAL THESIS} AND A MASTERS DISSERTATION

Five respondents indicated that criteria for differentiating between a masters

dissertation and a doctoral thesis had been laid down in their departments. Two of the five provided no further clarification, two indicated that the differences lay in scope and intensity, but provided no detail, while one enclosed the guidelines of her university for noting. According to these guidelines distinction is made in respect of scope, length, criteria applied in assessment and contribution to knowledge. The masters degree is described as a comparatively elementary research paper of defined scope and limited length $(+120$ pages A 4 paper, $11 / 4$ spacing) whereas the doctoral thesis is a considerably more demanding research paper which covers a wider field, or at least shows a greater sense of perspective, than does the Masters dissertation. There is no strict limitation on the length but 250-300 pages (A4, 11/4 spacing) would usually suffice.

The criteria applied in assessing the masters dissertation are technical competence, evidence of adequate scholarly research, critical ability, lucidity and coherence. A dissertation should have a theme or "thesis" which is implicit in the title, the degree to which the student sustains his/her theme is an important consideration

The general criteria applied in assessing the masters dissertation are applied in assessing the doctoral thesis but much more rigorously. In addition the extent to which the doctoral candidate reveals an extensive as well as intensive knowledge of his subject is assessed.

A masters dissertation is not required to be an original contribution to knowledge. Its primary purpose is a learning experience to acquire initial competence in conducting research. It should however contribute to our insight into or understanding of its subject. The doctoral thesis on the other hand should be an original contribution to knowledge.

\section{DISCUSSION}

The variety of masters programmes offered in this country and the diversity of descriptive titles for the masters degree in nursing is not unusual in the discipline of nursing. In the U.S.A. nurses completing a masters in nursing programme may be awarded a M.Sc. a M.S.N., a M.N., a M.A., a M.P.H. or M.N.S. The type of the degree awarded may be dependent upon requirements set by the university, or on the content of the programme as determined by the nursing faculty (Redman and Amos 1987:xxi).

The rate of growth of masters students in this country is however much lower than in the U.S.A. Whereas only about onequarter percent of all nurses registered with the S.A.N.C. were in possession of a masters degree within two decades after establishment of the programmes, in the U.S.A. about four percent of the employed population had obtained masters degrees over a similar period of time (Redman and Amos 1987:xix).

Similar trends with regard to variations in admission requirement revealed by this study, are noted in other countries. The diversity in the U.S.A. however appears more pronounced. As reported by Redman and Amos (1987:xxi) some programmes in the U.S.A. admit non-nurse students with a baccalaureate in another field of study, some admit registered nurses who have earned a non-nursing baccalaureate degree while some schools offer joint degrees with such disciplines as business, public health and health service administration, through collaborative programmes they have developed with another department or school within the college or university. The option of joint degrees is also found at the University of Edinburgh where the masters degree can be obtained in nursing and education or nursing and administration (correspondence with Head of Department of Nursing studies at Edinburgh

University). Some nursing departments in the U.K. admit registered diploma nurses who have proved themselves as experts or leaders in their field and who have scholarly publications to their name directly into a masters programme. Nevertheless the variations in admission pre-requirements in this country have raised a number of questions not addressed in this study, for example, besides resulting in a diversity of form, does it not also result in a diversity in programme length, structure and content? Further clarity needs to be obtained in this matter.

Even though as depicted in Table 3, all the suggested admission criteria received support from the majority of respondents, it may be useful to obtain more clarity on the reasons why a small proportion of respondents considered these criteria unimportant. On comparing the findings of this item with those obtained in a study done in university departments of English in South Africa, it was interesting to note that the ratings regarding specific criteria differed. In the ratings of lecturers of English, 1) choice of a suitable topic, 2) validation and outline of projected dissertation followed closely by

3) availability of specialist supervisor counted most heavily, while students record and examination performance to date was less favoured. On the other hand, in the ratings of nursing respondents both availability of specialist supervisor and students record and examination performance to date counted most heavily. A statement by Mauer (1984:56) on the latter criteria deserves attention and consideration. "The relationship between ready knowledge which is required in an examination situation and the activities required for successful completion of a dissertation is problematic. As far as can be established it has never been empirically demonstrated that examination performance can serve as a predictor of the following criteria to adequately identify a research problem, to initiate research, to carry out the necessary duties with regard to published research results and theories, to carry out the empirical work, to collect and analyse data and to interpret and report findings on the basis of existing works." (Translated)

Differences were also found with regard to certain aspects relating to supervisors and nature of supervision among English and nursing departments. All ten English departments respondents placed highest and equal priority on academic qualification of supervisors and their expertise or particular interest in the proposed field of study. Of the nine nursing respondents only one indicated that both expertise and academic qualification are considered. She gave as reason that the expert in the field does not always necessarily hold academic qualifications high enough to guide masters students, therefore both criteria should receive equal weighting.

At not even one-half of the nursing departments under study (4) were guidelines issued indicating the nature and scope of the supervisors responsibility vis a vis the masters candidate, whereas all the English departments made clear indications available. Guidelines on this aspect are important. If responsibilities are clear spelt out right at the start, there need be no false expectations on the part of the candidate, and no sense of guilt on the part of the supervisor. Perhaps the inexperienced can follow the lead of the more experienced in this respect.

The differences of opinion as to the duties of the supervisors in respect of the final draft of the dissertation among nursing respondents is a matter of concern A question which should be raised here is whether a supervisor who makes amendments or rewrites sections of his students work is not perhaps exceeding her brief. This is a matter which ought to be discussed among the various nursing departments, as it has a distinct bearing on the assessment of quality of the dissertation.

An important similarity found in all nursing departments as well as in departments of English is the requirement of at least one external examiner. This should contribute in maintaining similarity in standards. 


\section{LIMITATIONS OF THE STUDY}

The major limitation of this study concerned the use of questions which were too general and did not generate sufficient information. More indepth probing may have procured more meaningful data.

Furthermore the focus of the study was too limited. Inclusion of important aspects such as the major goal of masters programmes, assumptions underlying the programmes and curriculum content and structure would have clarified many uncertainties.

\section{CONCLUSION}

Despite the limitations, the information obtained through this survey should enable all concerned to pinpoint specific strengths and weaknesses in their policies. It also makes it possible to determine in which areas more collaboration among the various university lecturers concerned with masters programmes should occur, and in which areas more information is needed. It has in fact provided further scope for research.

\section{LIST OF SOURCES}

Baj, P.J. 1987. The Master's thesis: process, scope and outcome. Nurse Educator. 12 (1): 8-9.

Forni, P. 1987. Master's programs: the state of the art. Nursing and Health Care. 8 (1): $71-75$

Ketefian, S., Hagerty, B.K. 1987. Putting master's programs to the test. Nursing and Health Care. 8 (9): 503-507.

Kotze, W.J. 1970. Report on nursing education in the Republic of South Africa and the Territory. Pretoria: S.A.N.A.
Mauer, K.F. 1984. Toelatingsvereistes en registrasie van Magister en Doktorale studente. Progressio. 6 (2): 5-8.

May, K., Holzemer, W. 1985. Masters thesis policies in nursing education. Journal of Nursing Education. 24 (1): 10-15.

Pereira, E. 1984. The Master's degree in University departments of English Progressio. 6 (2): 28-36.

Redman, B.K., Amos, L.K. 1987. Guide to programs in nursing in four-year colleges and universities. New York: MacMillan Publishing Company.

Searle, C. 1968. Report on nursing education in the Republic of South and the Territory. Pretoria: S.A.N.A

H.I.L. Brink, D. Litt et Phil

Professor, Dept of Nursing Science University of South Africa

\section{ERRATUM}

In the article MEDIA USE AND PREFERENCE RELATED TO CORONARY HEART DISEASE OF THE COLOURED POPULATION OF THE CAPE PENINSULA THE CRISIC STUDY published in the July issue of Curationis Vol. 12, Nos 1 \& 2 the following particulars were omitted STEYN MARIANA M.Soc. Sc. Nursing, RN, RM, Dip. Paediatric Nursing, Dip. Clinical Care, Administration and Instruction, B.A Honn (Soc.), Institute for Communication Research, Human Sciences Research Council STEYN KRISELLA, M.Sc. N.E.D. M.D., The Centre for Epidemiological Research in Southern Africa, SA Medical Research Council 